\title{
Studies on Metabolic Pathways of Cyanate in Rats
}

\author{
Ichiro KOSHIISHI, Rie SHIBAYAMA, Yasuko MORIMOTO, and Toshio IMANARI \\ Faculty of Pharmaceutical Sciences, Chiba University, Yayoi-cho, Chiba-shi, Chiba, 260, Japan
}

(Received April 14, 1988)

\begin{abstract}
Metabolic pathways of cyanate in rats were studied by means of measurements of cyanate, carbamyl phosphate and S-carbamyl group. Approximately $30-50 \%$ of cyanate administered to rats $(0.5$ $\mathrm{mmol} / \mathrm{kg}$ body weight) was found in buffered gastric contents, and was also detected as ammonia liberated by acid hydrolysis. However, the gastric excretion of cyanate was a temporary phenomenon just after cyanate administration. Biliary and urinary excretion of cyanate and acid-soluble S-carbamyl group are minor metabolic pathways.
\end{abstract}

Keywords — cyanate; carbamyl; biliary excretion; urinary excretion; gastric excretion; rat; cyanase; uremia; uremic toxin

\section{Introduction}

Several investigators have demonstrated that cyanate has a variety of biological actions because of its chemical reactivity. ${ }^{1-4)}$ For example, cyanate inhibits in vitro or in vivo the sickling of erythrocytes from patients with sickle cell disease. ${ }^{1)}$ In this case, cyanate prevents hemoglobin $S$ agglutination due to the carbamylation of the amino-terminal residues of hemoglobin S. ${ }^{5}$ )

On the other hand, cyanate is known to be one of the uremic toxins. Some workers have inferred that cyanate is in chemical equilibrium with urea in the blood, and cyanate in plasma is increased under such disease conditions as diarrhea or renal failure, where the blood level of urea is elevated. ${ }^{2,3,6,7)}$

Cyanate administered to mammals disappears from the blood. In general, it is presumed that cyanate is catalytically hydrolyzed directly to $\mathrm{CO}_{2}$ and $\mathrm{NH}_{3}$ by cyanase. ${ }^{8)}$ In in vitro experiments, Holtham and Schütz ${ }^{8)}$ reported that cyanate was catalytically hydrolyzed by liver extract in the presence of orthophosphate. However, Collins and Anderson ${ }^{9)}$ concluded that a cyanase was not present in mammals, and the hydrolysis of cyanate in their experiments occurred by enzymatic hydrolysis of carbamyl phosphate, a condensation product of cyanate and orthophosphate.

Cerami et al. ${ }^{10)}$ showed that the injection of $\left[{ }^{14} \mathrm{C}\right]$ cyanate into a mouse led to the following distribution of radioactivity: $72 \%$ broken down to $\mathrm{CO}_{2}, 7 \%$ excreted in the urine and $7.5 \%$ incorporated for specific carbamylation of the $\mathrm{NH}_{2}$ terminal valine of hemoglobin. Johnson et al. ${ }^{11}$ ) reported that the hydrolysis of $\left[{ }^{14} \mathrm{C}\right]$ cyanate to $\left[{ }^{14} \mathrm{C}\right] \mathrm{CO}_{2}$ in mouse occurred only during the first 30 min after intraperitoneal cyanate administration. Recently, we have established methods for the determination of cyanate, ${ }^{12)}$ carbamyl phosphate ${ }^{12)}$ and S-carbamyl group ${ }^{13)}$ in biological materials. In this work, we studied the fate of cyanate in rat body using these analytical methods and attempted to elucidate the mechanism of cyanate hydrolysis.

\section{Materials and Methods}

Chemicals - Glutathione, trichloroacetic acid (TCA) and sodium cyanate were purchased from Wako Pure Chemicals (Osaka, Japan). All other chemicals were of reagent grade. Reagent solutions were prepared by dissolving reagents in deionized and distilled water. TSK gel SAX was obtained from Tosoh Co., Ltd. (Tokyo, Japan). A micropartition system (MPS-1) was purchased from Amicon Co. (U.S.A.). A standard solution of cyanate was prepared from sodium cyanate which had been recrystallized from ethanol, by dissolving it in distilled and deionized water before use.

Preparation of Rat Liver Extracts Fresh liver $(2.0 \mathrm{~g})$ was cut into small pieces, suspended in $2 \mathrm{ml}$ of $0.25 \mathrm{M}$ sucrose solution, and homogenized with a Potter-Elvehjem type glass 
homogenizer under cooling in an ice-water bath. The homogenate was made up to $5 \mathrm{ml}$ with $0.25 \mathrm{M}$ sucrose solution and centrifuged at 1000 $\times \boldsymbol{g}$ for $15 \mathrm{~min}$. All steps were carried out at 4 ${ }^{\circ} \mathrm{C}$. The supernatant was then dialyzed for $6 \mathrm{~h}$ at $4{ }^{\circ} \mathrm{C}$ against $0.01 \mathrm{M}$ Tris- $\mathrm{HCl}$ buffer, $\mathrm{pH} 7.2$, containing $5 \mathrm{~mm}$ magnesium chloride.

Determination of Cyanate and Carbamyl Phosphate - Cyanate and carbamyl phosphate were measured by a sensitive and specific high-performance liquid chromatographic (HPLC) method which was established by us. ${ }^{12)}$ The chromatographic conditions were as follows: column, TSK gel SAX $(4 \mathrm{~mm}$ i.d. $\times 50$ $\mathrm{mm}$ ); eluent, $75 \mathrm{mM} \mathrm{NaCl}$; column temperature, $20^{\circ} \mathrm{C}$. The detection was based on the indophenol reaction for the ammonia which was released by the hydrolysis of cyanate and carbamyl phosphate.

Determination of Acid-Soluble and AcidInsoluble S-Carbamyl Group - The Scarbamyl group was measured by a method established previously by us. ${ }^{13)}$ To $200 \mu \mathrm{l}$ of sample, $100 \mu 1$ of $20 \%(w / v)$ TCA was added with stirring. The mixture was left for $1 \mathrm{~h}$ at 37 ${ }^{\circ} \mathrm{C}$. After centrifugation at $10000 \times \boldsymbol{g}$ for $5 \mathrm{~min}$, one volume of the supernatant was added to one volume of $1.0 \mathrm{M} \mathrm{NaOH}$ and then subjected to HPLC (acid-soluble S-carbamyl group). The precipitate was washed twice with $7 \%$ TCA solution. After centrifugation at $10000 \times \boldsymbol{g}$ for 10 min, the supernatant solution was decanted as completely as possible and the precipitate was dissolved in $1.0 \mathrm{ml}$ of $1.0 \mathrm{M} \mathrm{NaOH}$. After standing for a few minutes, it was ultrafiltered with a micropartition system (MPS-1, Amicon Co.) and a $50 \mu 1$ portion of the filtrate was subjected to HPLC (acid-insoluble S-carbamyl group).

Determination of Ammonia - A $200 \mu \mathrm{l}$ portion of the sample solution obtained from biological materials was applied to a column (4.2 mm i.d. $\times 20 \mathrm{~mm}$ ) of Amberlite CG-120 (type II, $\mathrm{Na}^{+}$form). The column was washed three times with $1 \mathrm{ml}$ of $0.15 \mathrm{M} \mathrm{NaCl}$, then eluted with $1.0 \mathrm{M} \mathrm{NaCl}$, and fractions of $1.0 \mathrm{ml}$ were collected. To each fraction, $0.5 \mathrm{ml}$ of $2 \%(\mathrm{w} / \mathrm{v})$ aqueous phenol solution containing $10 \mathrm{mg} / \mathrm{dl}$ sodium nitroprusside was added. The mixture was shaken vigorously for $30 \mathrm{~s}$, then $0.5 \mathrm{ml}$ of $1 \%(\mathrm{w} / \mathrm{v})$ aqueous sodium hydroxide solution containing $0.1 \%(\mathrm{w} / \mathrm{v})$ sodium hypochlorite was added. The reaction mixture was shaken for $30 \mathrm{~s}$ and kept for $15 \mathrm{~min}$ at $37^{\circ} \mathrm{C}$. Then the absorbance of the reaction mixture was measured at $635 \mathrm{~nm}$ against a reagent blank solution.

Analysis of Urine - Cyanate (1.0 $\mathrm{mmol} / \mathrm{kg}$ ) was administered intraperitoneally to Wistar rats $(200 \pm 5 \mathrm{~g}$, male) and they were housed in a metabolic cage. The urine was pooled in an ice-water bath during the experiment, and then subjected to cyanate and Scarbamyl group assay.

Analysis of Bile - Polyethylene tubing was inserted to a rat bile duct, and bile was collected with cooling in an icc-water bath at regular time intervals after subcutaneous administration of cyanate. The bile was made up to adequate volume with distilled and deionized water, then cyanate and acid-soluble S-carbamyl group were determined.

Measurement of Cyanate in Stomach Six milliliters of $50 \mathrm{~mm}$ aqueous hydrochloric acid solution (for ammonia assay) or $50 \mathrm{~mm}$ aqueous trisodium citrate solution (for cyanate assay) was given by stomach tube to male Wistar rats $(200 \pm 5 \mathrm{~g})$ fasted for $6 \mathrm{~h}$, and sodium cyanate $(0.5 \mathrm{mmol} / \mathrm{kg})$ was administered intraperitoneally. Thirty minutes after cyanate administration, the stomach was removed and its content was suspended in distilled and deionized water. The suspension was shaken vigorously for $1 \mathrm{~min}$ and centrifuged at $3000 \times$ $\boldsymbol{g}$ for $10 \mathrm{~min}$. The supernatant was subjected to ammonia or cyanate assay.

\section{Results and Discussion}

\section{State Analysis of Cyanate in Rat Tissues}

Cyanate administered to mammals is incorporated to tissues and reacts with sulfhydryl group to form $\mathrm{S}$-carbamyl group. ${ }^{13)}$ This reaction is reversible. ${ }^{14)}$ The fates of cyanate and $\mathrm{S}$ carbamyl group in rat tissues after cyanate administration are shown in Fig. 1. In plasma, cyanate existed in the free form. On the other hand, in liver and kidney, cyanate existed mainly as acid-soluble S-carbamyl group together with a small amount of free cyanate. In red blood cells, 

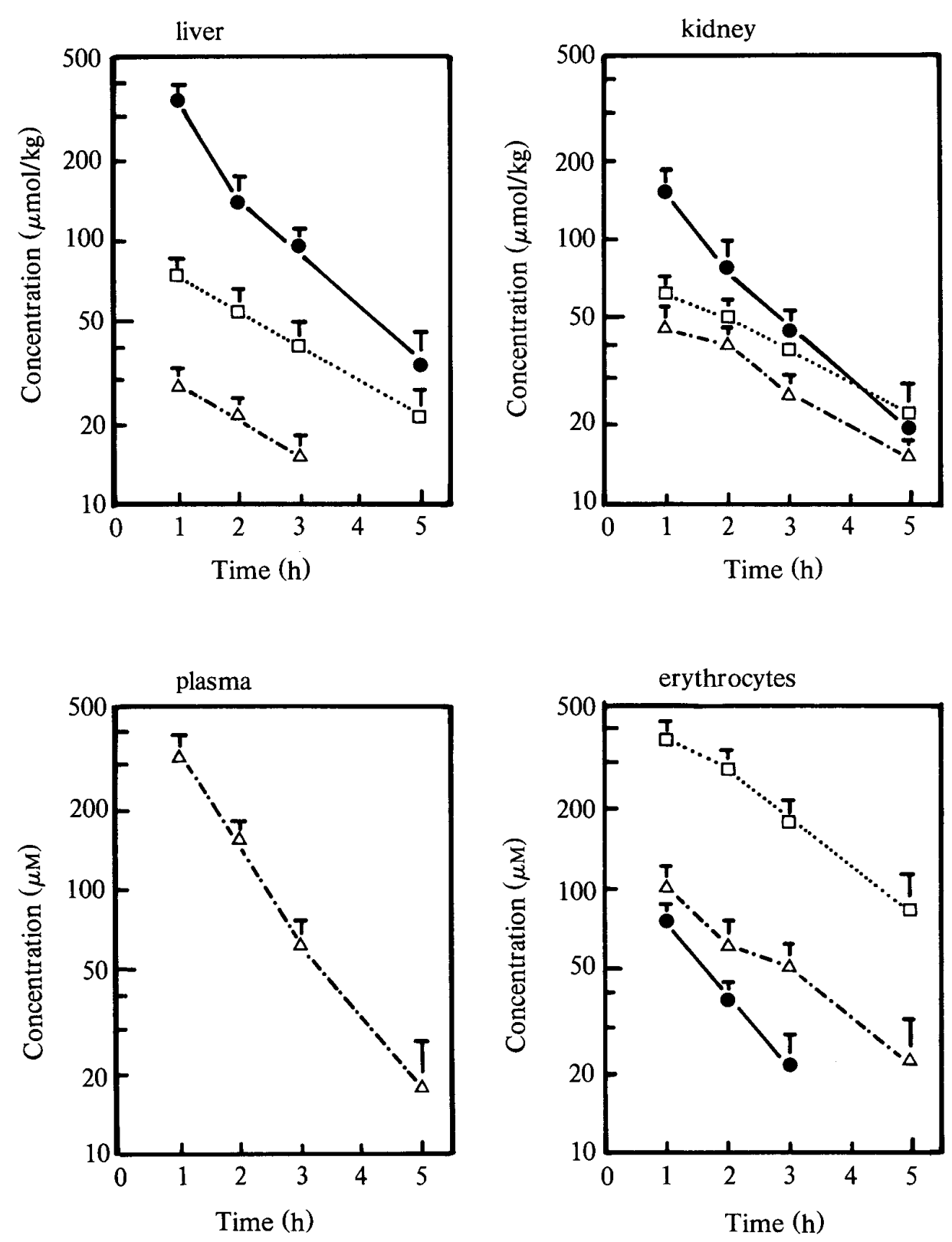

Fig. 1. Time Courses of Cyanate and S-Carbamyl Group Levels in Rat Blood, Liver, and Kidney after Cyanate Administration

Wistar male rats $(200 \pm 5 \mathrm{~g})$ were given sodium cyanate $(0.5 \mathrm{mmol} / \mathrm{kg})$ intraperitoneally. Each data point shows the mean \pm S.E. of three rats. $\bullet$, acid-soluble S-carbamyl group; $\square$, acid-insoluble S-carbamyl group; $\triangle$, cyanate.

acid-insoluble S-carbamyl group was the major component, and cyanate and acid-soluble $S$ carbamyl group were minor. In the organs, acidsoluble S-carbamyl group decreased more rapidly than cyanate.

\section{Urinary Excretion of Cyanate}

Renal carbonic anhydrase, ${ }^{15}$ ) having a single zinc atom per single-chain peptide, plays an important role in the reabsorption of water from renal tubules. Cyanate is an inhibitor of this metallo-enzyme and causes diuresis. ${ }^{16)}$ When cyanate is administered to mammals, a part of the cyanate may be excreted in the urine without reabsorption from renal tubules. Table I shows that about $2.4 \%$ of administered cyanate was excreted in the urine within $3 \mathrm{~h}$ after the administration of cyanate. The $\mathrm{pH}$ of the urine was alkalized because of the inhibition of carbonic anhydrase by cyanate.

Biliary Excretion of Cyanate 
TABLE I. Urinary Excretion of Cyanate and Acid-Soluble S-Ca:bamyl Group

\begin{tabular}{lccc}
\hline \hline & $\begin{array}{c}\text { Cyanate ion } \\
(\mu \mathrm{mol})\end{array}$ & $\begin{array}{c}\text { Acid-soluble S-carbamyl group } \\
(\mu \mathrm{mol})\end{array}$ & $\begin{array}{c}\text { Total } \\
(\mu \mathrm{mol})\end{array}$ \\
\hline Control rats & $<0.01$ & $<0.01$ & \\
Cyanate-administered rats & $4.53 \pm 0.86$ & $0.18 \pm 0.12$ & $4.71 \pm 0.93$ \\
\hline
\end{tabular}

Rats were administered intraperitoneally sodium cyanate $(1.0 \mathrm{mmol} / \mathrm{kg})$ and the urine was collected for $3 \mathrm{~h}$. Control rats were administered intraperitoneally sodium chloride $(1.0 \mathrm{mmol} / \mathrm{kg})$ instead of sodium cyanate. Each value represents the mean \pm S.E. of four analyses.

TABLE II. Biliary Excretion of Cyanate and Acid-Soluble S-Carbamyl Group

\begin{tabular}{ccccc}
\hline $\begin{array}{c}\text { Time period } \\
(\mathrm{h})\end{array}$ & $\begin{array}{c}\text { Cyanate ion } \\
(\mu \mathrm{mol})\end{array}$ & $\begin{array}{c}\text { Acid-soluble } \\
\text { S-carbamyl group }(\mathrm{A}) \\
(\mu \mathrm{mol})\end{array}$ & $\begin{array}{c}\text { Total }(\mathrm{B}) \\
(\mu \mathrm{mol})\end{array}$ & $\begin{array}{c}\mathrm{A} / \mathrm{B} \\
-\end{array}$ \\
\hline$-1-0$ & $<0.01$ & $<0.01$ & 1.43 & 0.78 \\
$1-1$ & $0.311 \pm 0.028$ & $1.12 \pm 0.21$ & 1.21 & 0.91 \\
$1-2$ & $0.111 \pm 0.013$ & $0.731 \pm 0.019$ & 0.705 & 0.69 \\
$3-4$ & $0.328 \pm 0.035$ & $0.381 \pm 0.016$ & 0.508 & 0.54 \\
$4-5$ & $0.324 \pm 0.053$ & $0.197 \pm 0.008$ & 0.39 & 0.09 \\
\hline
\end{tabular}

Rats were administered intraperitoneally sodium cyanate $(1.0 \mathrm{mmol} / \mathrm{kg})$. Each value represents the mean $\pm \mathrm{S} . \mathrm{E}$. of three analyses.

TABLE III. Amount of Ammonia in Stomach after Cyanate Administration to Rats

\begin{tabular}{|c|c|c|c|}
\hline \multicolumn{2}{|c|}{ Control rats } & \multicolumn{2}{|c|}{ Cyanate-administered rats } \\
\hline $\begin{array}{c}\text { Amount of ammonia } \\
\text { in stomach } \\
(\mu \mathrm{mol})\end{array}$ & $\begin{array}{l}\text { Cyanate level } \\
\text { in plasma } \\
(\mathrm{mm})\end{array}$ & $\begin{array}{l}\text { Amount of ammonia } \\
\text { in stomach } \\
(\mu \mathrm{mol})\end{array}$ & $\begin{array}{l}\text { Cyanate level } \\
\text { in plasma } \\
(\mathrm{mM})\end{array}$ \\
\hline $20.6 \pm 8.7$ & N.D. & $72.4 \pm 9.7$ & $0.311 \pm 0.020$ \\
\hline
\end{tabular}

N.D., not detected $(<2.0 \mu \mathrm{M})$. Six milliliters of $50 \mathrm{~mm}$ hydrochloric acid was given by stomach tube to rats $(200 \pm 5$ $\mathrm{g})$, and sodium cyanate $(0.5 \mathrm{mmol} / \mathrm{kg})$ was administered intraperitoneally. Thirty minutes after administration, the stomach was removed and the content was collected. Each value represents the mean \pm S.E. of five analyses.

In the liver, a substance which is soluble and has molecular weight greater than a certain threshold tends to be excreted into the bile. As shown in Table II, both acid-soluble S-carbamyl group and cyanate were excreted in the bile. The proportion of acid-soluble S-carbamyl group in the bile decreased with the passage of time. The acid-soluble S-carbamyl group excreted in bile may be transported to the duodenum and degraded to cyanate, and the cyanate may be hydrolyzed by enterobacterial cyanase ${ }^{17)}$ or reabsorbed.

\section{Gastric Excretion of Cyanate}

Epithelial cells of the stomach excrete inorganic ions by both active and passive transport in to the stomach. ${ }^{18)}$ Consequently, it was considered that a part of cyanate administered to a rat might be excreted into the stomach. Gastric ammonia was determined to examine the excretion of cyanate into the stomach, because cyanate is labile under acidic conditions and is quickly hydrolyzed to ammonia. On the other hand, the excretion of cyanate into the stomach was examined directly when trisodium citrate so- 
TABLE IV. Gastric Excretion of Cyanate

\begin{tabular}{ccc}
\hline $\mathrm{pH}$ of gastric content & $\begin{array}{c}\text { Amount of cyanate in stomach } \\
(\mu \mathrm{mol})\end{array}$ & $\begin{array}{c}\text { Cyanate level in plasma } \\
(\mathrm{mm})\end{array}$ \\
\hline $5.32 \pm 0.21$ & $33.8 \pm 2.0$ & $0.361 \pm 0.05$ \\
\hline
\end{tabular}

Six milliliters of $50 \mathrm{~mm}$ trisodium citrate aqueous solution were given by stomach tube to rats ( $200 \pm 5 \mathrm{~g})$, and sodium cyanate $(0.5 \mathrm{mmol} / \mathrm{kg})$ was administered intraperitoneally. Thirty minutes after administration, the stomach was removed and the content was collected. Each value represents the mean \pm S.E. of four analyses.

lution was placed in the stomach to increase the $\mathrm{pH}$ of the gastric juice and suppress the hydrolysis of cyanate. Table III shows the amount of ammonia in stomach of rats $(200 \pm 5 \mathrm{~g})$ at 30 min after intraperitoneal administration of 0.5 mmol cyanate $/ \mathrm{kg}$. Table IV shows the amount of cyanate in the stomach of rats at $30 \mathrm{~min}$. These results suggested that, during the first 30 min after cyanate administration, approximately $30-50 \%$ of cyanate was excreted into the stomach and hydrolyzed quickly to carbon dioxide and ammonia. Further, sodium cyanate $(0.5$ $\mathrm{mmol} / \mathrm{kg}$ ) was administered intraperitoneally to rats $(200 \pm 5 \mathrm{~g})$ fasted for $6 \mathrm{~h}$, and at $30 \mathrm{~min}$ after cyanate administration, $6 \mathrm{ml}$ of $50 \mathrm{~mm}$ aqueous trisodium citrate solution was given by stomach tube. At $1 \mathrm{~h}$ after cyanate administration, the cyanate ion in the stomach was determined. However, cyanate could not be detected in the stomach. This result suggests that the gastric excretion of cyanate is temporary after cyanate administration. It is presumed that the hydrolysis of $\left[{ }^{14} \mathrm{C}\right]$ cyanate reported by Cerami $e t$ al. ${ }^{10)}$ and Johnson et al. ${ }^{11)}$ may be caused by the

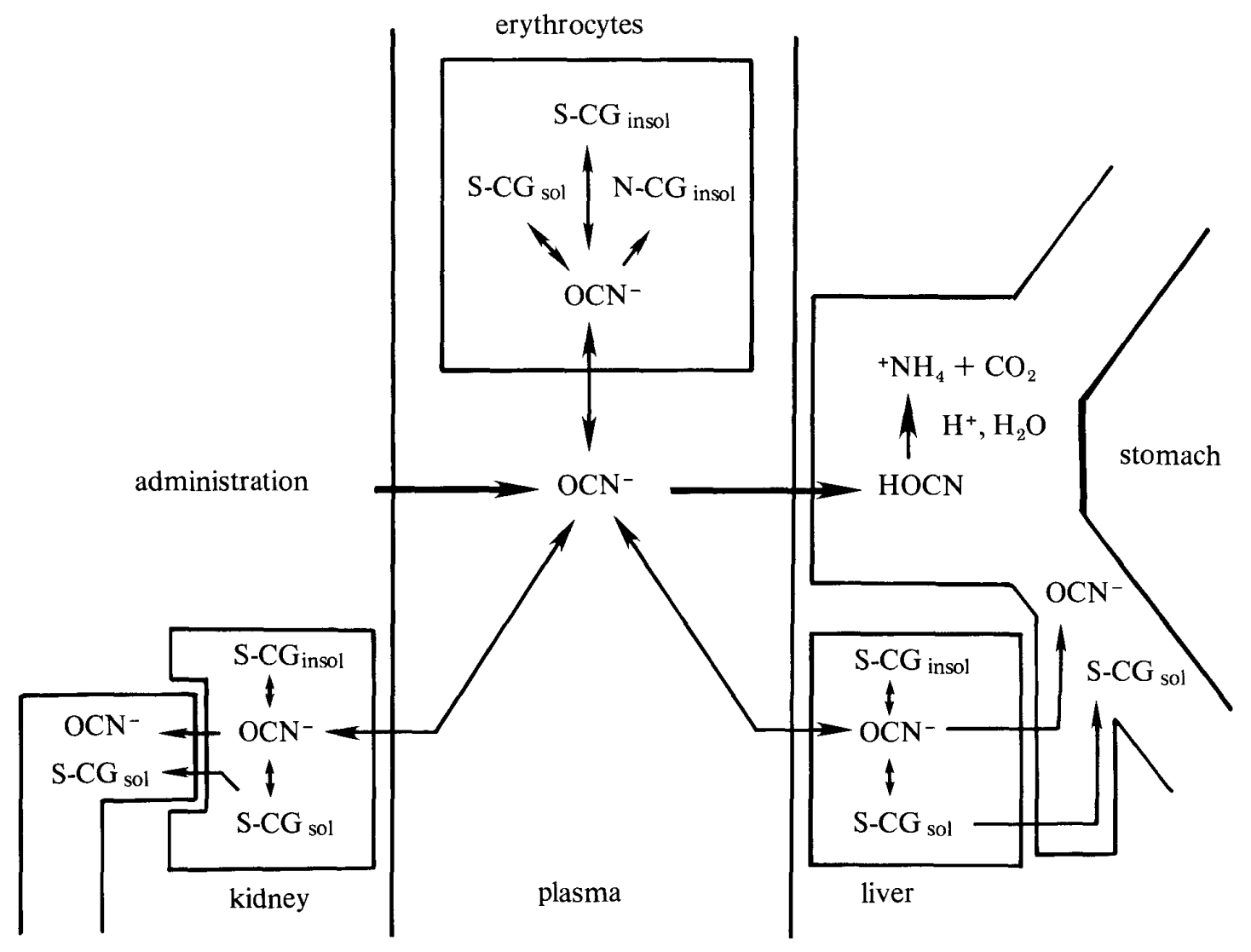

Fig. 2. Possible Fate of Cyanate in Rats after Intraperitoneal Administration

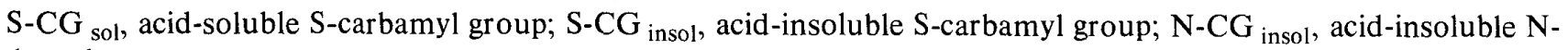
carbamyl group. 
gastric excretion of cyanate. The fate of cyanate in the rat body is summarized in Fig. 2. As described above, cyanate administered to rats intraperitoneally is partially excreted initially into the stomach and hydrolyzed by $\mathrm{HCl}$. The remaining cyanate is distributed widely in the rat body and gradually decreased by urinary excretion, biliary excretion, or other metabolic pathways which are presently unknown.

\section{References}

1) A. Cerami and J. M. Manning: Potassium cyanate as an inhibitor of the sickling of erythrocytes in vitro, Proc. Natl. Acad. Sci. U.S.A., 68, 1180-1183 (1971).

2) S. Erill, R. Calvo and R. Carlos: Plasma protein carbamylation and decreased acidic drug protein binding in uremia, Clin. Pharmacol. Ther., 27, 612-618 (1980).

3) J. J. Harding and K. R. Rixon: Carbamylation of lens proteins: A possible factor in cataractogenesis in some tropical countries, Exp. Eye Res., 31, 567-571 (1980).

4) M. A. Lea, M. R. Koch and H. P. Morris: Tumorselective inhibition of the incorporation of ${ }^{3} \mathrm{H}$-labeled amino acids into protein by cyanate, Cancer Res., 35, 2321-2326 (1975).

5) C. K. Lee and J. M. Manning: Kinetics of the carbamylation of the amino groups of sickle cell hemoglobin by cyanate, J. Biol. Chem., 248, $5861-5865$ (1973).

6) P. Dirnhuber and F. Schütz: The isomeric transformation of urea into ammonium cyanate in aqueous solutions, Biochem. J., 42, 628-632 (1948).

7) P. Hagel, J. J. T. Gerding, W. Fieggen and H. Bloemendal: Cyanate formation in solutions of urea, Biochim. Biophys. Acta, 243, 366-373 (1971).
8) S. B. Holtham and F. Schütz: Cyanase, a new enzyme catalysing the hydrolysis of cyanate, Experimentia, 4, 398-399 (1948).

9) C. A. Collins and P. M. Anderson: Hydrolysis of cyanate catalyzed by guinea pig and rat tissue extracts, Biochem. Biophys. Res. Commun., 79, 1255-1260 (1977).

10) A. Cerami, T. A. Allen, J. H. Graziano, F. G. Defuria, J. M. Manning and P. N. Gillette: Pharmacology of cyanate. I. General effects on experimental animals, $J$. Pharmacol. Exp. Ther., 185, 653-665 (1973).

11) J. D. Johnson, P. R. Mayer and G. E. Isom: Pharmacokinetic analysis of potassium cyanate in mice using whole blood and expired air, Drug Metab. Dispos., 13, 260-262 (1985).

12) I. Koshiishi, J. Isono and T. Imanari: Simultaneous determination of cyanate and carbamyl phosphate by high performance liquid chromatography, Anal. Sci., 2, $81-85$ (1986)

13) I. Koshiishi and T. Imanari: Determination of Scarbamyl group in biological materials, Anal. Sci., 3, 59-62 (1987).

14) G. R. Stark: On the reversible reaction of cyanate with sulfhydryl groups and the determination of $\mathrm{NH}_{2}$ terminal cysteine and cystine in proteins, J. Biol. Chem., 239, 1411-1414 (1964).

15) H. F. Deutsch: Carbonic anhydrases, Int. J. Biochem., 19, $101-113$ (1987).

16) T. H. Maren and G. Sanyal: The activity of sulfonamides and anions against the carbonic anhydrases of animals, plants, and bacteria, Ann. Rev. Pharmacol. Toxicol., 23, 439-459 (1983).

17) P. M. Anderson: Purification and properties of the inducible enzyme cyanase, Biochemistry, 19, $2882-2888$ (1980).

18) L. R. Johnson: Gastric secretion, "Gastrointestinal Physiology," ed. by E. D. Jacobson, The C. V. Mosby Company, Saint Louis, 1977, Chapter 7. 